\title{
Lupus La Protein
}

National Cancer Institute

\section{Source}

National Cancer Institute. Lupus La Protein. NCI Thesaurus. Code C142145.

Lupus La protein (408 aa, $\sim 47 \mathrm{kDa}$ ) is encoded by the human SSB gene. This protein is involved in the modulation of tRNA and mRNA metabolism. 